\title{
Designtænkning som didaktisk metode: \\ - læringsdesign for teknologisk forestillingskraft og handlekraft
}

\section{Rikke Berggreen Paaskesen}

Voksenunderviser og efterskolelærer

Rikke Berggreen Paaskesen er cand.pæd. i sociologi og har undervist i pædagogik og i didaktik på VIA University College. I øjeblikket er hun voksenunderviser på FOF i tysk sprog, kultur og samfundsforhold samt lærer på Klank Efterskole, hvor hun underviser i open-ended projects med brug af Mindstorm robotteknologi samt i sprog.

\section{Rikke Toft Nørgård}

Associate professor in educational design and technology

Rikke Toft Nørgård er associate professor in educational design \& technology på Center for Undervisningsudvikling og Digitale Medier, Aarhus Universitet. Hendes arbejde fokuserer på innovation i undervisning og læring gennem brugen af designtænkning, uddannelsesfilosofi og hybridt læringsdesign.
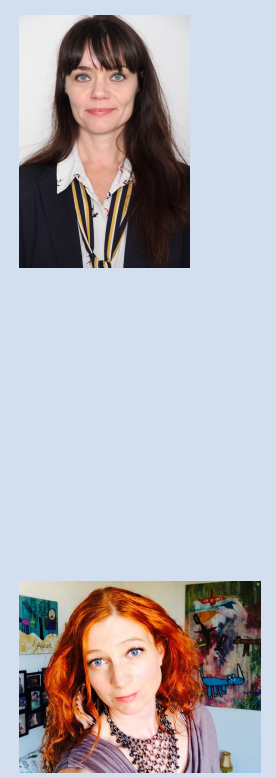


\section{Abstract (dansk)}

Det er et problem, at undervisere, lærerstuderende og elever ikke bliver mødt med tilstrækkelige didaktiske metoder og processer til, hvorledes de kan anvende teknologier i undervisningen på måder, der understøtter elevens teknologiske forestillingskraft og handlekraft. Dette forsøger denne artikel at adressere gennem at tilbyde en generel forståelsesramme, struktur, model samt et konkret case-eksempel for, hvorledes man kan arbejde med designtænkning som didaktisk metode til anvendelse af teknologier i undervisningen.

Artiklen kobler designtænkning og læringsdesign sammen til designtænkende læringsdesign, der sigter mod at opøve og fremme såvel underviserens som den studerendes teknologiske forestillingskraft og handlekraft. Designtænkende læringsdesign for teknologisk forestillingskraft og handlekraft præsenteres dernæst gennem en konkret case: Future-Tech-Town Year 2060.

I konklusionen udvides perspektivet til uddannelsesarbejde med læringsdesign, der inddrager teknologier på måder, der sigter mod at fremme kritisk-kreative fremtids-skabere.

\section{Abstract (engelsk)}

It is a problem that teachers, students, and pupils are not supported with sufficient pedagogical methods and processes for utilizing and using technologies in education in ways that support their technological imagination and agency. The article tries to adress this problem by offering a general framework, process, and model for this, as well as present a concrete case for how to work with design thinking as pedagogical method when integrating technologies into education. The article combines design thinking and learning design to design thinking learning designs that aim to foster and promote teachers', students', and pupils' technological imagination and agency. Design thinking learning designs for technological imagination and agency is then ilustrated through a concrete case: Future-Tech-Town Year 2060. In conclusion, educational development in the form of learning designs that integrate technologies in ways that aim to promote critical-creative futuremakers are also adressed.

\section{Introduktion}

I "Educating for innovation" (2006) skriver Sawyer, at "analysts emphasize the importance of creativity, innovation and ingenuity in the knowledge economy. In fact some scholars refer to today's economy as a creative economy [...] powered by human creativity" (Sawyer, 2006, s. 41). Sawyer fremhæver dernæst det faktum, at uddannelsespraktikere og -tænkere ikke har været særligt gode til at praktisere og indtænke teknologiens indtog $\mathrm{i}$ vores samfund i de måder, de gor og tanker uddannelse på: "students are taught that knowledge is static and complete, and they become experts in consuming knowledge rather than producing knowledge" (Sawyer, 2006, s. 47).

Hvis vi i uddannelse ønsker, at vores børn og unge skal udvikle innovationskompetence, sådan som det er indskrevet i den seneste skolelov, forudsætter det, at både nuværende og kommende undervisere ved, hvorledes man udformer og udfører innovative læringsdesign og -aktiviteter (Paaskesen, 2015; Nørgård \& Paaskesen, 2016; Nørgaard \& Brandt, 2016; Nørgaard \& 
Charlton, 2016). Det er ikke tilstrækkeligt med gode intentioner på et overfladisk informationsniveau, hvor viden om kreativitet, innovation og entreprenørskab transmitteres fra underviser til studerende. Hvis fremtidige undervisere og studerende skal besidde innovationskompetence, må vi bevæge os ud over konventionelle læringsdesign, der blot transmitterer viden om et emne og forlade, hvad Paulo Friere kalder 'the banking model of education' (Freire, 1974). Det er heller ikke tilstrækkeligt for studerende og elever at deltage i projekter, der sigter mod fremstilling af kreative eller innovative produkter. Læringsdesign, der sigter mod rene produktionsforløb, ender ofte i, hvad Paulo Blikstein kalder 'the keychain syndrome' (Blikstein, 2013), hvor produktfremstilling gennem brug af teknologier kommer til at stå i stedet for teknologiske læreprocesser. Endelig er det på ingen måde tilstrækkeligt at forestille sig, det kommer til at ske automatisk ved at indskrive det i vejledningen til fagene i skolen; at nu skal lærerne undervise i entreprenørskab og innovation (Folkeskoleloven, 2015). Snarere forudsætter opøvelsen af innovationskompetence - hvad vi her kalder teknologisk forestillingskraft og handlekraft (se nedenfor) - åbne eksplorative og eksperimenterende læringsdesign, der har en indlejret praktisering af, hvad vi andetsteds har kaldt for 'open-ended education' eller åben (ud)dannelse (Nørgård \& Paaskesen, 2016). I artiklen blev åbne læringsteknologier, åbne læringsdesign og åbne læringskontekster kombineret til et rammeværk for praktiseringen af åben (ud)dannelse, der sigter mod at understøtte og fremme teknologisk forestillingskraft og handlekraft (Nørgård \& Paaskesen, 2016). Rammeværket blev ligeledes fremvist i praksis gennem casen 'Coding Pirates Future Island.' I artiklen blev det vist, hvorledes anvendelsen af åbne læringsteknologier, der rammer en balance mellem 'directing' og 'emergent' læring (Valk, Bekker \& Eggen, 2013) i åbne læringsdesign, der er iterative åbne læringscyklusser af 'imagine, create, play, share reflect' (Resnick, 2007) og har åbne designprojekter, udforskning og afprøvning af ideer, divergent tænkning og kritisk-kreativ tænkning som centrale elementer (Kwon, Park \& Park, 2006). Endelig blev det vist gennem casen 'Coding Pirates Future Island', hvorledes åbne teknologier $\mathrm{i}$ åbne læringsdesign behøvede åbne læringskontekster for at kunne opnå det iboende potentiale for at understøtte og fremme teknologisk forestillingskraft og handlekraft på måder, der skabte kontakt med og engagement $\mathrm{i}$ omverden og samfund. Tilsammen udgør det hvad Deputy Director for the OECD Directorate of Education karakteriserer som 21st century learning:

"Education today is as much about ways of thinking, which involve creative and critical approaches to problem-solving and decisionmaking. It is also about ways of working, including communication and collaboration, as well as the tools they require, such as the capacity to recognize and exploit the potential of new technologies, or indeed, to avert their risks. And last but not least, education is about the capacity to live in a multifaceted world as an active and engaged citizen. These citizens influence what they want to learn and how they want to learn, and it is this that shapes the role of educators". (Schleicher, uden sidetal \& årstal) 
Case og rammeværk for åben (ud)dannelse var dog i artiklen målrettet uformelle læringsdesigns og -kontekster, selvom også dets potentialer og muligheder i forbindelse med formel (ud)dannelse blev beskrevet (Nørgård \& Paaskesen, 2016). Denne artikel bygger videre på dette arbejde, dels gennem casen Future-Tech-Town Year 2060 at vise hvorledes sådanne åbne læringsdesign for teknologisk forestillingskraft og handlekraft kan finde sted også i formelle læringskontekster, dels ved at udbygge rammeværket så det bliver robust ind i en formel uddannelseskontekst men på måder så den iterative, processuelle, kritisk-kreative forestillings- og handlekraft bevares. Dette sker ved at udvikle designtænkning som didaktisk metode $\mathrm{i}$ formelle maker- og teknologiorienterede læringskontekster gennem at kombinere

- designtænkning inden for det professionsorienterede \& uddannelsesmæssige felt (Nelson \& Stolterman, 2012; Cross, 2011; Schön, 1987; Edelson, 2009; Collins, Joseph \& Bielaczyc, 2009; Nørgård, 2015),

- makeology \& makerspaces (Blikstein, 2013; Papert, 1980; Papert, 2000; Walter-Hermann \& Büching, 2013; Peppler, Halverson \& Kafai, 2016a; Peppler, Halverson \& Kafai, 2016b),

- teknologisk forestillingskraft (Resnick, 1998; Resnick 2007; Selwyn, 2008; Balsamo, 2011; Nørgård \& Brandt 2016; Nørgård \& Charlton, 2016; Nørgård \& Paaskesen, 2016; Toft \& Nørgård, 2016),

- kreativitetsfremmende undervisning (Bear, 2013; Dettmer, 2005; Craft, Cremin, Hay \& Clack, 2014; Daniels, 2013; Sawyer, 2012; Martinez \& Stager, 2013; Gregerson, Snyder \& Kaufman, 2013),

- handlekraft og åbenhed $i$ undervisningen (Holmberg, 2014; Biesta, Priestley \& Robinson, 2015; Guskey, 2010; Laurillard, 2008; Priestley, Biesta \& Robinson, 2015) og

- læringsdesign (Conole, 2013; Dalziel et al., 2016; Laurillard, 2012; Maina, Craft \& Mor, 2015; Mor, 2013; Mor \& Craft, 2012; Conole, Dyke, Oliver \& Seale, 2004; Goodyear, 2005)

Ovenstående udgør sammenlagt fundamentet for artiklens udvikling af designtænkning som didaktisk metode til udviklingen og praktisering af læringsdesign, der understøtter teknologisk forestillingskraft og handlekraft hos undervisere og studerende, når de arbejder med teknologier $\mathrm{i}$ formelle læringskontekster. Udviklingsarbejdet understøttes ydermere af den mangeårige udvikling og afprøvning af metoden gennem design eksperimenter og design baseret forskning i uddannelsesmæssige kontekster (Cobb et al., 2003; Anderson \& Shattuck, 2012). Arbejdet med dele af ovenstående rammeværk har tidligere været behandlet i bl.a. Nørgård \& Paaskesen, 2016; Nørgård \& Brandt, 2016; Nørgård \& Charlton, 2016; Nørgård, 2015, hvor også forløbene Coding Pirates Future Island, Future-Fantasy Technology Role-Play og Coding Pirates Playing the Refugee Crisis præsenteres og gennemgås som eksempler på aspekter af dette fundament. I herværende artikel samles trådende med fokus på udvikling og praktisering af didaktisk designtænkning [design science \& design thinking] gennem læringsdesign [learning design], der understøtter teknologisk forestillingskraft [technological imagination] og handlekraft [agency] i formelle læringskontekster. Rammeværket er sammensat med 
henblik på at kunne designe for højere-ordens læring med teknologier i formelle læringskontekster.

Disse læringsdesigns og læreprocesser rækker ud over, hvad der ofte forsøges dækket med termer såsom digitale færdigheder, digitale kompetencer eller digital dannelse (Poore, 2011; Skov, 2015; Skov \& Brøndum, 2015). Teknologisk forestillingskraft og teknologisk handlekraft sigter ikke mod det at anvende teknologier, forstå teknologier eller begå sig med teknologier hvad Dettmer i "New Blooms in established fields: four domains of learning and doing" (2005) kalder for 'Basic Learning' og 'Applied Learning' - men i højere grad mod det at være divergent tænkende (forestillingskraft) og kritiskkreativt producerende (handlekraft) medborger med teknologier - hvad Dettmer kalder for 'Ideational Learning' - og som er de højeste niveauer inden for læring; der, hvor vi formår at tænke nyt, udforske, forundres, eksperimentere, innovere, konstruere og komme frem til overraskende løsninger eller fortællinger (Dettmer, 2005, s. 73). Højere-ordens læring - eller ideational learning - er altså karakteriseret ved det produktive møde mellem forestillingskraft og handlekraft på måder, der er åbne, afprøvende, improviserende og fokuserer på, hvad den lærende stræber efter, drømmer om og vil skabe et argument for. Ideational Learning ligger således tæt op ad, hvad OECD Directorate of Education oven for karakteriserede som 21st century learning.

\begin{tabular}{|c|c|c|c|c|c|}
\hline \multicolumn{4}{|c|}{ BASIC LEARNING: Phases 1 and 2 with near (low-road) transfer of learning. } & \multicolumn{2}{|c|}{$\begin{array}{l}\text { Characterized by REALISM } \\
\text { (What should learners know?) }\end{array}$} \\
\hline \multicolumn{6}{|c|}{$\begin{array}{l}\text { ACQUISITION. Rudimentary. Is requisite for all learners. Educator teaches, learner masters. The content is necessary, the } \\
\text { process is structured, and the context domain designates the standard(s). Time is provided for mastery and compensatory } \\
\text { alternatives are supplied as needed if mastery is not possible. }\end{array}$} \\
\hline Baseline & Cognizant & Sentient & Conscious & Aware & Viable \\
\hline Phase 1 & Know & Receive & Observe & Relate & Perceive \\
\hline Phase 2 & Comprehend & Respond & React & Communicate & Understand \\
\hline \multicolumn{4}{|c|}{ APPLIED LEARNING: Phases $3,4,5$ with far (high-road) transfer of learning. } & \multicolumn{2}{|c|}{$\begin{array}{l}\text { Characterized by PRAGMATISM } \\
\text { (What can learners do?) }\end{array}$} \\
\hline \multicolumn{6}{|c|}{$\begin{array}{l}\text { Developmental } \\
\text { UTILIZATION. Co } \\
\text { process is flexible }\end{array}$} \\
\hline Phase 3 & Apply & Value & Act & Participate & Use \\
\hline Phase 4 & Analyze & Organize & Adapt & Negotiate & Differentiate \\
\hline Phase 5 & Evaluate & Internalize & Authenticate & Adjudicate & Validate \\
\hline \multicolumn{4}{|c|}{ IDEATIONAL LEARNING: Phases 6, 7, 8 with original construction/production. } & \multicolumn{2}{|c|}{$\begin{array}{l}\text { Characterized by IDEALISM } \\
\text { (To what do learners aspire?) }\end{array}$} \\
\hline \multicolumn{6}{|c|}{$\begin{array}{l}\text { Generative } \\
\text { INNOVATION. New. Is to be personalized for every learner. Educator facilitates, learner generates. The content is novel, the } \\
\text { process is open ended, and the domain supports uniqueness. Diverse outcomes of accomplishment are anticipated and } \\
\text { encouragement is offered to enable learner fulfillment. }\end{array}$} \\
\hline Phase 6 & Synthesize & Characterize & Harmonize & Collaborate & Integrate \\
\hline Phase 7 & Imagine & Wonder & Improvise & Initiate & Venture \\
\hline Phase 8 & Create & Aspire & Innovate & Convert & Originate \\
\hline
\end{tabular}

Som vi skal se neden for, er især design tænkning og makeology produktive felter, når ærindet er at skabe et rammeværk for udvikling og praktisering af læringsdesign for teknologisk forestillingskraft og handlekraft. Design tænkning og makeology skal dernæst sættes $i$ tæt forbindelse med det didaktiskpædagogiske forskningsfelt, for at undervisningen og læringen bliver både værdifuld, relevant og meningsfuld. Her er tænkning inden for kreativitetsfremmende undervisning og læringsdesign væsentlige veje at gå, hvis 
formålet er at holde fokus på højere-ordens forestillingskraft og handlekraft i formelle læringskontekster og opbygge en ambitiøs model, der sigter mod dette og ikke blot mod nuværende konceptualiseringer af digitale færdigheder, digitale kompetencer eller digital dannelse, der i højere grad befinder sig på de lavere-rangerende niveauer. Det betyder selvsagt ikke, at disse lærings-niveauer er irrelevante eller unødvendige, men en pointering af at det at være kreativ, innoverende eller fantasifuld med teknologier på reflekterede måder kræver noget andet og mere. Ærindet for artiklen er på en begyndende måde at pege på, hvorledes dette andet og mere kan begribes og praktiseres som læringsdesign i formelle læringskontekster.

\section{Designtænkning som didaktisk metode}

Åben (ud)dannelse i formelle læringskontekster der sigter mod opøvelsen af teknologisk forestillingskraft og handlekraft blandt undervisere og studerende kræver en overskridelse af 'the banking model of education', hvor viden overdrages fra underviser til studerende for derefter at blive bragt $\mathrm{i}$ anvendelse (Freire, 1974; Gregersen, Snyder \& Kaufman, 2013; Craft, Cremin, Hay \& Clack, 2014; Sawyer, 2006; Sawyer, 2012). Det er således ikke tilstrækkeligt at vide, hvad en bestemt teknologi er, eller hvordan den fungerer og anvendes korrekt. Det er mindst lige så vigtigt at studerende og undervisere ved, hvorfor de vil efterfølge en bestemt ide gennem anvendelse af bestemte teknologier, hvorfor de vil engagere sig i bestemte problemstillinger gennem teknologisk forestillingskraft og handlekraft og hvorfor det er vigtigt og relevant at gøre det på netop denne måde. Ovenstående kræver, at underviser og studerende har opøvet en kritisk-kreativ tilgang til teknologier, hvor bestemte ideer eller problemstillinger kan afsøges, udforskes, afprøves og reflekteres over - hvad vi i (Nørgård \& Paaskesen, 2016) har kaldt 'technological imagination \& enterprising' og som har tæt affinitet til, hvad man kunne kalde for 'teknologisk design visdom', hvor design visdom er kendetegnet ved at være den rette ting, for de rette folk, på det rette tidspunkt, på det rette sted, på den rette måde, af de rette grunde (Cross, 2011). Fremhævningen af evnen til på kritisk-kreativ vis at kunne syntetisere forestillingskraft og handlekraft (også) i arbejdet med teknologier som er at finde i Dettmers begreb om 'ideational learning' (2005) er også implicit tilstede i revisionen af Blooms taxonomi fra 2001, hvor substantiver (produkter) blev erstattet af verber (processer) og hvor 'syntese' og 'vurdering' (informationstransmission) blev erstattet af 'at skabe' (deltagelsesprocesser), (Andersen \& Kratwohl, 2001). I højere-ordens læring går man således fra forståelse af teknologier ('hvad' eller 'basic learning') til anvendelse af teknologier ('hvordan' eller 'applied learning') til teknologisk forestillingskraft udtrykt gennem handlekraft ('hvorfor' eller 'ideational learning'). 


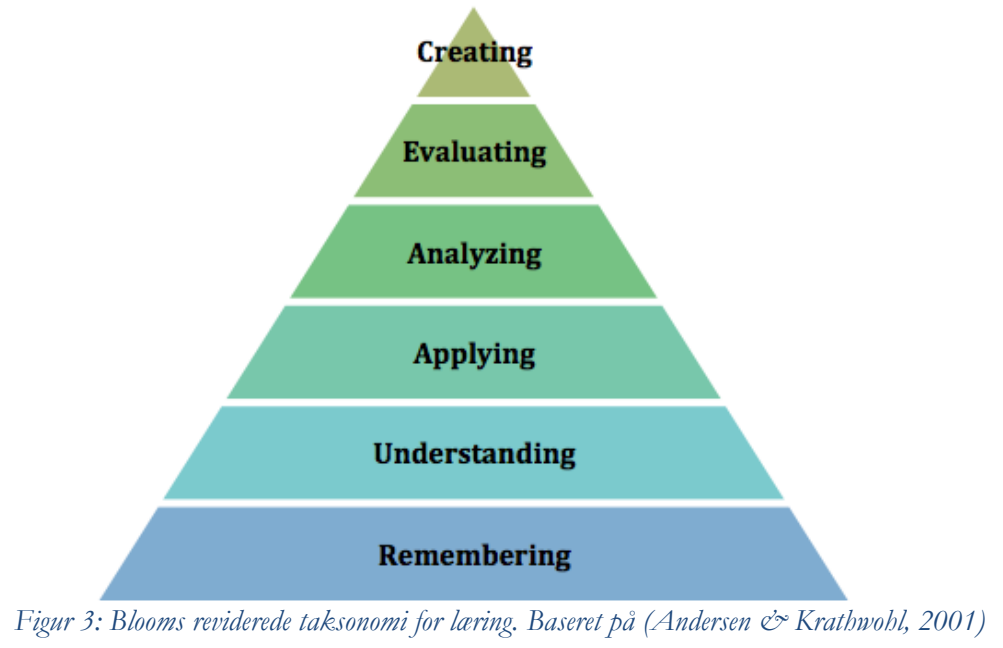

Behovet for gennem læringsdesign at understøtte og fremme teknologisk forestillingskraft og handlekraft gennem opøvelsen af design visdom bliver ydermere tydelig, når man kigger nærmere på den seneste folkeskolelov. Her står det formuleret, at entreprenørskab og innovation nu skal implementeres i skolens fag, herunder i danskfaget: "Lærerne skal nu arbejde systematisk med at designe innovative læreprocesser for eleverne $i$ skolen (...) Der skal nu også være fokus på fagets kreative og skabende elementer. Udfordringen består nu ikke kun $\mathrm{i}$ at undervise om innovation (...) men i innovative læringsaktiviteter, der har til formål at udvikle elevernes innovationskompetence"1. I forbindelse med denne artikel forstås entreprenørskab ud fra et didaktisk perspektiv som en praksisform, hvor undervisere og studerende er uddannede til at opdage, afprøve og realisere nye værdiskabende muligheder (Saywer, 2012). Kreativitetsbegrebet er oprindeligt et teologisk og humanistisk begreb, som man har forbundet med 'guddommelig inspiration', 'geniets intuition' eller 'det legende barn' (Paaskesen, 2015), som udspringer fra det latinske udtryk creatio ex nibilo, at skabe ud af intet. Ud fra et mere nutidigt kreativitetsbegreb anskues kreativitet ikke som en privilegeret evne eller guddommelig inspiration, men snarere som noget der kan opøves. Det er en evne til at arbejde åbent og produktivt med begrænsninger (Florida, 2012; Negus \& Pickering, 2004), der bevæger sig mellem divergerende idegenerering og konvergerende konstruktion af en ide eller løsning, der omformer, overskrider eller nytænker allerede eksisterende elementer eller felter i verden (Knobel \& Lankshear, 2015). Kreativitet kan på den måde siges at udtrykke sig gennem reflekteret konvergent problem-løsning eller divergent fremtids-skabelse (Nørgård \& Brandt, 2016) - noget, der kræver evnen til 'ideational learning' med teknologier - hvad vi kalder for teknologisk forestillingskraft og handlekraft. Dette indebærer alt sammen, at hvis vi ønsker at uddanne folk, som kan udforske, afprøve, opfinde og være innovative med teknologier, så er vi nødt til at have undervisere, der kan igangsætte og facilitere teknologiske læringsdesigns på måder, der understøtter og fremmer dette.

\footnotetext{
${ }^{1}$ Vejledning for faget dansk, afsnit 3.3
} 
Det er ud fra ovenstående således ikke tilstrækkeligt med læringsdesign som informationsdesign, der overbringer viden om teknologi, innovation og designprocesser, ej heller læringsdesign som produktdesign, der sigter mod fremstillingen af produkter. Det er læringsdesign som procesdesign, der inddrager de studerende i åbne kritisk-kreative undersøgelsesprocesser med teknologier. Gennem åbne processuelle læringsdesign der inddrager teknologier på måder, der sigter mod teknologisk forestillingskraft, opstår produkter som en del af processen, ikke som resultatet af processen. Med andre ord bliver produkterne og teknologierne en integreret del af læringsdesignet og læreprocessen - hvad Yishay Mor kalder 'objects to think with' og 'objects to talk with' (Mor, 2013). Her er produkter og teknologibrug ikke målet med processerne men indgår i processen som det, der forvandler den indre forestilling til eksternaliseret handling og den individuelle tanke til en fælles fortælling. Objekterne bliver midtpunkt i - og ikke udkomme af læringsdesignet. Det er således læringsdesign, der arbejder med teknologisk forestillingskraft og handlekraft i undervisningen ud fra en anerkendelse af, at dette bedst opnås gennem et kontinuerligt kritisk-pædagogisk og refleksivt processuelt arbejde. Et arbejde der forudsætter vedvarende genovervejelser, tilpasninger, omkalfatringer af didaktisk tænkning, pædagogisk arbejde og teknologisk designpraksis. Teknologisk forestillingskraft eksternaliseres således omkring 'objects to talk with' fremstillet gennem åbne divergerende og konvergerende designprocesser. Design tænkning er således som felt fokuseret på sådanne divergerendekonvergerende eller 'abduktive' processer og erkendelsesformer, hvor forestillingskraft kommer til udtryk gennem handlekraft og handlekraft reflekteres kritisk gennem forestillingskraften. En sådan designprocessuel erkendelsesform adskiller sig fra 'induktive' og 'deduktive' erkendelsesformer, som er traditionelle vidensformer i vores uddannelsessystem:

"Logic has lost interest in abstract forms. Science investigates
extant forms. Design initiates novel forms. A scientific hypothesis is
not the same thing as a design hypothesis. A logical proposition is
not to be mistaken for a design proposal. A speculative design
cannot be determined logically, because the mode of reasoning
involved is essentially abductive (...) It is this hypothesizing of what
may be, the act of producing proposals or conjectures that is so
central to designing".
(Cross 2011:27)

Abduktiv didaktisk design tænkning peger således frem mod, hvad der kunne være - mod 'ideational learning' - og designprocesser synes således velegnede til at understøtte og fremme teknologisk forestillingskraft og handlekraft. Abduktive processer fremmer evnen til design tænkning, eller hvad Nelson og Stolterman kalder evnen til 'intentional change in an unpredictable world' (Nelson \& Stolterman, 2012) gennem at veksle mellem åbent og legende at undersøge og underholde mulige forestillinger og tanker (divergent designtænkning) og eksperimenterende og afprøvende at finde frem til de mest velegnede handlinger, fortællinger og konstruktioner (konvergent designtænkning). Det kræver dog, at designprocesserne tænkes didaktisk som 
læringsdesign, for at de kan blive værdifulde, relevante og meningsfulde $\mathrm{i}$ en formel læringskontekst.

Vi må altså som uddannere og undervisere være $\mathrm{i}$ stand til at skabe didaktiske rammer og vilkår for, at lærerstuderende kan opøve teknologisk forestillingskraft og handlekraft gennem abduktive processer, først i deres egen praksis og dernæst i deres praksis med elever. Dette kalder på underviseres kompetence til at udvikle og praktisere didaktisk design tænkning som læringsdesign, hvor lærere under uddannelse kan opøve teknologisk forestillingskraft og handlekraft ind i deres fagligheder - og således derigennem integrere dem i deres (kommende) undervisningspraksis.
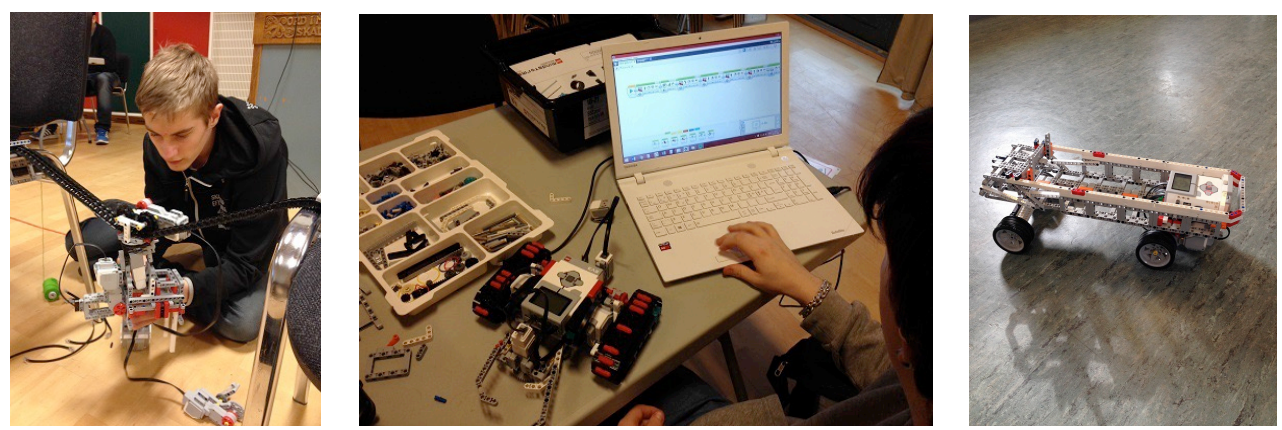

Figur 2: Billeder fra laringsdesignet Future-Tech-Town Year 2060, der sigter mod at opbygge teknologisk forestillingskraft og bandlekraft blandt elever i 9.-10. klasse (billeder af Rikeke Berggreen Paaskesen).

Dette arbejde forsøger denne artikel at understøtte og lette gennem at tilbyde en forståelsesramme, struktur, procesmodel og et konkret case-eksempel for hvorledes man kan arbejde med designtænkning som didaktisk metode til udformningen af læringsdesign for kritisk-kreativ teknologisk forestillingskraft og handlekraft. Gennem opbygningen af rammeværk og modeller for designtænkende læringsdesign og læringsdesign for designtænkning med teknologier for demokratisk dannelse, der bevæger sig ud over læringsdesign, der imiterer tavleundervisning eller produktfremstilling frem mod abduktive læringsdesign, som åbne processer. Designtænkende læringsdesign benytter divergente og konvergente teknologiprocesser i underviseres og studerendes praksis, der udfolder sig som en dialog mellem designarbejde og designargument, designvision og designrealitet, der sigter mod opøvelsen af kritisk-kreativ designvisdom for teknologisk pro-aktivt medborgerskab.

Neden for præsenteres først abduktiv designtænkning og divergente og konvergente designprocesser. Dernæst kobles designtænkning og læringsdesign sammen til didaktisk design tænkning som metode for undervisere og studerende. Denne metode beskrives dernæst som udviklingen og praktiseringen af åbne læringsdesign for teknologisk forestillingskraft og handlekraft, idet centrale strukturer, elementer og faser fremstilles og beskrives. Dette leder frem til sammenkoblingen af 'design inquiry' og 'teacher inquiy' gennem inddragelsen af kritisk pædagogik og 'teacher agency' for demokratisk dannelse illustreret med det læringsdesign, der gives med casen Future-TechTown Year 2060. 


\section{Didaktisk designtænkning og læringsdesign}

Designtænkning og læringsdesign kan siges at være supplementære og understøtte hinanden, når formålet er skabelsen af deltagelsesprocesser for teknologisk forestillingskraft og handlekraft gennem udtænkningen og konstruktionen af 'objects to talk with' (Mor, 2013) gennem brug af nye teknologier. Designtænkning omfortolket som didaktisk metode kan hjælpe underviseren med at designe undervisning for eksploraitve og eksperimenterende processer med teknologier på måder, der sigter mod 'ideational learning.' Dette er i tråd med Laurillards pointering af, at undeviserens rolle ikke er: "to transmit knowledge to a passive recipient, but to structure the learner's engagement with the knowledge, practicing the highlevel cognitive skills that enable them to make that knowledge their own" (Laurillard, 2008, s. 527). Ved at tage designtænkning som didaktisk udgangspunkt muliggøres et skifte mod mere abduktive, processuelle, åbne, problemløsende (konvergent) og idegenerende (divergent) læringsformer. Resultat og produktfokus (substantiver) erstattes af deltagelses- og procesfokus (verber), hvor den lærende afprøver, udforsker og eksperimenterer gennem kritisk-kreativ designtænkning (Nelson \& Stolterman, 2012; Cross, 2011). I sådanne får underviseren en rammesættende rolle som dialog-, samarbejds- og faciliteringspartner, og læringsdesignet har til formål gradvist at opøve teknologisk forestillingskraft og handlekraft gennem iterative cyklusser af udforskning, fortolkning, idegenerering, afprøvning og refleksion omkring konstruktion af teknologiske 'objects to talk with' - nye samtaler i verden, der er skabt gennem fælles kritisk-kreative udforskningsprocesser med nye teknologier (Mor, 2013).

I didaktisk designtænkning sker der et fokusskifte væk fra læring af fakta (Freires 'banking model of education' og Dettmers 'basic learning') og fremstilling af produkter (Bliksteins 'keychain syndrome' og Dettmers 'applied learning') frem mod udforskning af mulige fremtider og alternative løsninger (Nelson \& Stoltermans 'abduktiv tænkning' og Dettmers 'ideational learning'). Ud fra denne designprocessuelle tilgang til undervisningen kan vi definere udviklingen og praktiseringen af abduktive læringsdesign som "the creative and deliberate act of devising new practices, plans of activity, resources and tools aimed at achieving particular educational aims in a given context" (Mor \& Craft, 2012, s. 86). Vigtigt er dog at bemærke at designtænkning som didaktisk metode bør suppleres med fagdidaktisk viden, pædagogisk teori, teknologisk indsigt og praksiserfaring på en sådan måde, at det understøtter og fremmer didaktisk refleksion inden for alle disse felter for såvel underviser som elev/studerende (Mor \& Craft, 2012). Det vil sige, at den 'klassiske' designtænkning (Nelson \& Stolterman, 2012; Cross, 2011; Schön, 1987), der er hjemmehørende udenfor det didaktiske felt skal suppleres med didaktiske metoder og teorier, der tilsammen skaber en didaktisk designtænkning, der er værdifuld, relevant og meningsfuld, ikke kun for uddannelse af professionelle designere og entreprenører, men for alle, der vil opøve evnen til teknologisk forestillingskraft og handlekraft i såvel læreprocesser som i livspraksis.

Designtænkning i kombination med læringdesign og didaktisk handlekraft (teacher agency) er en lovende model for integration af teknologier i undervisningen på måder, der understøtter teknologisk forestillingskraft og handlekraft på værdifulde, relevante og meningsfulde måder $i$ formelle 
læringskontekster. Her stiller designtænkningens velafprøvede iterative designprocesser sig til rådighed som åbne abduktive læreprocesser, der giver rum til eksplorativ og eksperimentel idegenerering og problemløsning med teknologier. Her bliver det også klart at en udfordring for underviserne består i at skabe læringsdesign, der understøtter og fremmer den lærendes udforskning, undersøgelse, afprøvning, konstruktion og refleksion med teknologier i undervisningen (Maina, M., Craft, B. \& Mor, Y., 2015). Med andre ord har vi brug for et skifte, hvor såvel undervisere som studerende er abduktivt tænkende 'læringsdesignere'.

Sammenlagt finder vi at åbne processuelle læringsdesign kan støtte og hiælpe undervisere $i$ bestræbelsen på at integrere teknologi i formelle læringskontekster på måder der udvikler teknologisk forestillingskraft og handlekraft gennem fremstillingen af 'objects to talk with' og 'objects to think with' (Mor, 2013) og opøvelsen af 'idea power' (Papert, 1980; Papert, 2000). Som Seymor Papert selv fremlægger sin position: "I wanted to show that some very powerful ideas could be brought into the lives of children through the mediation of digital technology..” (Papert, 2000, s. 722). Paperts fremhævelse af 'idea power' (ideational learning) på bekostning af teknologianvendelse (applied learning) understreger potentialet ved designtænkning som didaktisk metode:

"As an educator and friend of children I saw new oppertunities for
children to understand, to love, and to use ideas that had
previously been inaccessible to them. As an epistemologist I found
that thinking about computers as mediators between children and
ideas led me to a better understanding of several aspects of ideas-
of some particular ideas, of the nature of ideas in general and
especially of how they come to inhabit people". (Papert, 2000: 722)

Her kan et abduktivt læringsdesign på samme vis, gennem iterative processer af divergent forestillingskraft og konvergent handlekraft med teknologier, med hjælp fra underviserens kvalificerende og fagdidaktiske praksis, indlejre sig som en del af studerendes måde at tænke på i idégenererings- og problemløsningsprocesser med teknologier. En designprocessuel tilgang til teknologier understøtter den nuværende og fremtidige underviser i udvikling og praktiseringen af læringsdesign for teknologisk forestillingskraft og handlekraft. Herigennem sker et skifte fra læringsdesign, der har fokus på det allerede eksisterende (fakta og resultater) til ønskværdige fremtider (designvisioner) (Cross, 2011). Denne synsvinkel positionerer abduktiv teknologisk uddannelsespraksis som 'an act of design', ikke i kunstnerisk henseende, men "as a goal-directed, problem-solving activity that results in the creation of something useful that did not exist before" (Ertmer, P.A., Parisio, M.L. \& Wardak, D., 2013, s. 5-19). Designtænkning som didaktisk metode bliver således udgangspunktet for at bevæge de lærende mod den fremtid (designvision), de sigter efter, gennem opøvelsen af en forståelse for designtænkningens forskellige faser: udforskning, opdagelse, idegenerering, afprøvning, udvikling (se figur 4). Denne opøvelse i fremtids-skabelse i form af 
idégenerering og problemløsning kvalificeres og udvikles gennem udvikling og afprøvning af læringsdesign, der anvender teknologier på abduktive, åbne og designtænkende måder.

Selvom begrebet om læringsdesign (Learning Design) stadig mangler en fælles overensstemmelse omkring terminologien, så er der forsøg på udformningen af en sådan. Et eksempel er The Larnaca Declaration on Learning Design (Dalziel et al., 2016), der trækker på en analogi fra musikalsk notation. Ligesom i musikalsk notation gives der her et bud på et notations-system for at beskrive og dele idéer i et fælles sprog, hvilket har haft en effektfuld virkning for musikere til at kunne udveksle og dele deres musikalske idéer med hinanden. En sådan notations-form, som uddannere (ligesom musikere) kan anvende $\mathrm{i}$ deres undervisningsmiljøer, omtaler Dalziel som "educational notation" (Maina et al., 2015, s. 4). En sådan 'uddannelses notation' kan anvendes som en strukturel ramme, der sigter mod udformningen af læringsdesign, der understøtter og skaber et flow for aktiviteter. 'Uddannelses-notation' muliggør således overdragelsen af læringsdesign mellem undervisere, således at det bliver muligt at vidensdele undervisningsidéer, hvilket har været et centralt omdrejningspunkt inden for læringsdesign. Andre bud på processuel 'uddannelses-notation' er Shulmans 'signaturpædagogik' (Shulman, 2005) og Mors 'design patterns' (Mor, 2013).

Læringsdesign skal således ikke anskues som en pædagogisk teori. Der er snarere tale om en pædagogisk meta-struktur, uafhængig af specifikke pædagogiske teorier, der kan ligges ind $i$ disse strukturer. Læringsdesign tilstræber udviklingen af generelle rammeværk eller notationssystemer og har på den måde en affinitet til de processuelle fasemodeller, man finder inden for designtænkningen. Ligesom modeller for designprocesser kan rammeværk for læringsdesign beskrive mange forskellige typer undervisnings- og læringsaktiviteter (Dalziel et al., 2016). Læringsdesign kan således både være induktive, deduktive og abduktive af natur, ligesom forskellige læringsdesigns kan være tilkoblet forskellige underliggende pædagogiske teorier. Overordnet set peger forskningen på behovet for en eksperimenterende og udforskende tilgang til udarbejdelsen af læringsdesign, hvor forskere og praktikere i samarbejde med hinanden fungerer som "on-thespot researchers", der gennem vedvarende dialog med hinanden (Holmberg, 2014) og den kontekst de befinder sig i, udformer læringsdesign som en dialektik mellem 'teacher inquiry' (Maina et al., 2015) og 'design inquiry' (Nelson \& Stolterman, 2012). Udformningen af abduktive læringsdesign og processer gennem design didaktiske dialoger mellem forskning og praksis afspejles også i herværende artikel. Rikke Berggreen Paaskesen er pædagogisk sociolog og lærer på en efterskole, mens Rikke Toft Nørgård er design- og uddannelsesforsker og underviser på Center for Undervisningsudvikling og Digitale Medier, Aarhus Universitet. Dette dialogiske samarbejde på tværs af sektorer og domæner, der blev påbegyndt i 2014 og også er beskrevet i (Nørgård \& Paaskesen, 2016) har vist sig særligt frugtbart for en praksis- og forsknings-funderet udformning af abduktive læringsdesign for teknologisk forestillings- og handlekraft. Sawyer peger på at sådanne tværdisciplinære og tværsektorielle møder kan være særligt vigtige, når formålet er at tænke nyt snarere end at undersøge det eksisterende: "the most important creative 
insights typically emerge from collaborative teams and creative circles" (Sawyer, 2006, s. 42). Conole peger ligeledes på, at netop mødet mellem læringspraktikere og designtænkere er særligt vigtigt, hvis vi vil skabe værdiskabende og meningsfulde læringsdesign:

"A methology for enabling teachers/designers to make more informed decisions in how they go about designing, which is pedagogically informed and makes effective use of appropriate resources and technologies. This includes the design of resources and individual learning activities right up to whole curriculum level design. A key principle is to help make the designprocess more explicit and shareable. Learning design as an area of research and development includes both gathering empirical evidence to better understand the designprocess as well as the development of a range of resource, tools and activities". (Conole 2013: 121)

I denne artikels møde mellem læringsdesign og designprocesser, læringspraksis og designtænkning, undervisning og forskning er fokus på udformningen af konkrete abduktive læringsdesign for teknologisk forestillingskraft og handlekraft ('learning design') og ikke på udformningen af generelle strukturer for læringsdesign ('Learning Design') (Dalziel et al., 2016, s. 8). Et sådant konkret eksempel vil blive givet neden for, men først gives en nærmere indføring $i$ designtænkning som didaktisk metode, hvor teknologisk forestillingskraft og handlekraft opstår gennem åbne processer.

\section{Åbne processer for teknologisk forestillingskraft og handlekraft}

Designtænkende læringsdesign og læringsdesign for designtænkning for teknologisk forestillings- og handlekraft, som det er fremstillet i herværende artikel, bygger konkret på de udviklede, afprøvede og beskrevne læringsdesign: Coding Pirates Future Island (Nørgård \& Paaskesen, 2016), Coding Pirates Playing the Refugee Crisis (Nørgaard \& Charlton, 2016), Future-Fantasy Technology Role-Play (Nørgård \& Brandt, 2016) og Future-Tech-Town Year 2060 (denne artikel). Gennem processerne discovery, interpretation, ideation, experimentation, evolution (se figur 4) opøves undervisere og studerende i abduktive erkendelsesformer og læreprocesser. Underviserens rolle er således at integrere abduktive designprocesser med teknologier som didaktisk metode i undervisningen på måder, der understøtter såvel det dannelsesmæssige som fagdidaktiske sigte med undervisningen. Det vil sige at abduktive designprocesser fungerer som et rammeværk for udformningen af læringsdesign, idet underviseren anvender designtænkning med teknologier som 'pædagogisk form' (Laurillard, 2008) i kraft af gennem designtænkning som didaktisk metode at anskue sig selv om læringsdesigner $i$ egen undervisningspraksis (Laurillard, 2012).

Denne form for tilgang til teknologi kommer blandt andet til udtryk i, hvad man kan kalde Lego Mindstorms modulære teknologidesign. Her er robotternes fleksible og modulære bygge-system designet med henblik på at invitere brugeren til at opfinde, bygge og dele deres egne robotkonstruktioner 
og -fortællinger. Det betyder dog på ingen måde, at man derved automatisk er sikret læringsdesign, der understøtter og fremmer teknologisk forestillingskraft og handlekraft, når Lego Mindstorm robotter bruges i undervisningen. Hvis undervisere blot anvender de forhåndenværende trinvise programmeringsanvisninger, som findes i Mindstorm materialet, skifter læringen fra abduktiv designtænkning til produktbygning. Det er således ikke nok i sig selv at anvende modulære robotteknologier eller programmering $i$ undervisningen - her må fokus være på udformningen af abduktive læringsdesigns og på, hvorvidt de indeholder strukturer, der kalder på udviklingen af teknologisk forestillingskraft og handlekraft, sådan som det er beskrevet oven for.

Designprocesser, som beskrevet oven for og vist i figur 4, er hovedmotor $\mathrm{i}$ udviklingen og praktiseringen af åbne abduktive teknologiske læringsdesign, såfremt vi vil fremme kreativitet, innovation og entreprenørånd (Bear, 2013; Daniels, 2013). Det er kvaliteter, som forudsætter læringsdesign, der muliggør en eksplorativ og eksperimenterende tilgang til såvel undervisning som læringsdesign (Sawyer, 2006, s. 42), hvor læringsdesignet udformes, så det ikke låser læreprocessen fast og sigter mod bestemte resultater eller identiske forløb, men åbner læreprocessen således at såvel undervisere som studerende kan anskues som læringsdesignere i processen. Abduktive læringsdesign opstår således i en dialektisk vekselvirkning mellem det ønskværdige (designvision) og det opstående (designrealitet). Således forudsætter designtænkning som didaktisk metode muligheden for fleksibel tilpasning i mødet mellem underviser-ledede og studenter-ledede processer og aktiviteter (Craft, A., Cremin, T., Hay, P. \& Clack, J., 2014, s. 23).

For at sikre at designtænkningen som didaktisk metode forholder sig til den formelle læringskontekst, hvori læringsdesignet udspiller sig, er det brugbart at samtænke designprocesser med fx Blooms taxonomi, Dettmers ideational learning eller lignende didaktiske formater. Igennem etableringen af dialektikker mellem det designteoretiske og didaktiske felt; designprocesser og læringsdesign opstår et rum for at fremme teknologisk forestillingskraft, innovation og entreprenørskabsånd i formelle skolekontekster, sådan som det er indskrevet $\mathrm{i}$ den nye Folkeskolelov og efterspurgt af blandt andet OECD. Denne måde at lære at tænke og arbejde på i åbne projekter i uformelle og i formelle læringskontekster er yderligere udfoldet i (Nørgård \& Charlton, 2016; Nørgård \& Brandt, 2016; Aaen \& Nørgård, 2015; Nørgård, 2015). 


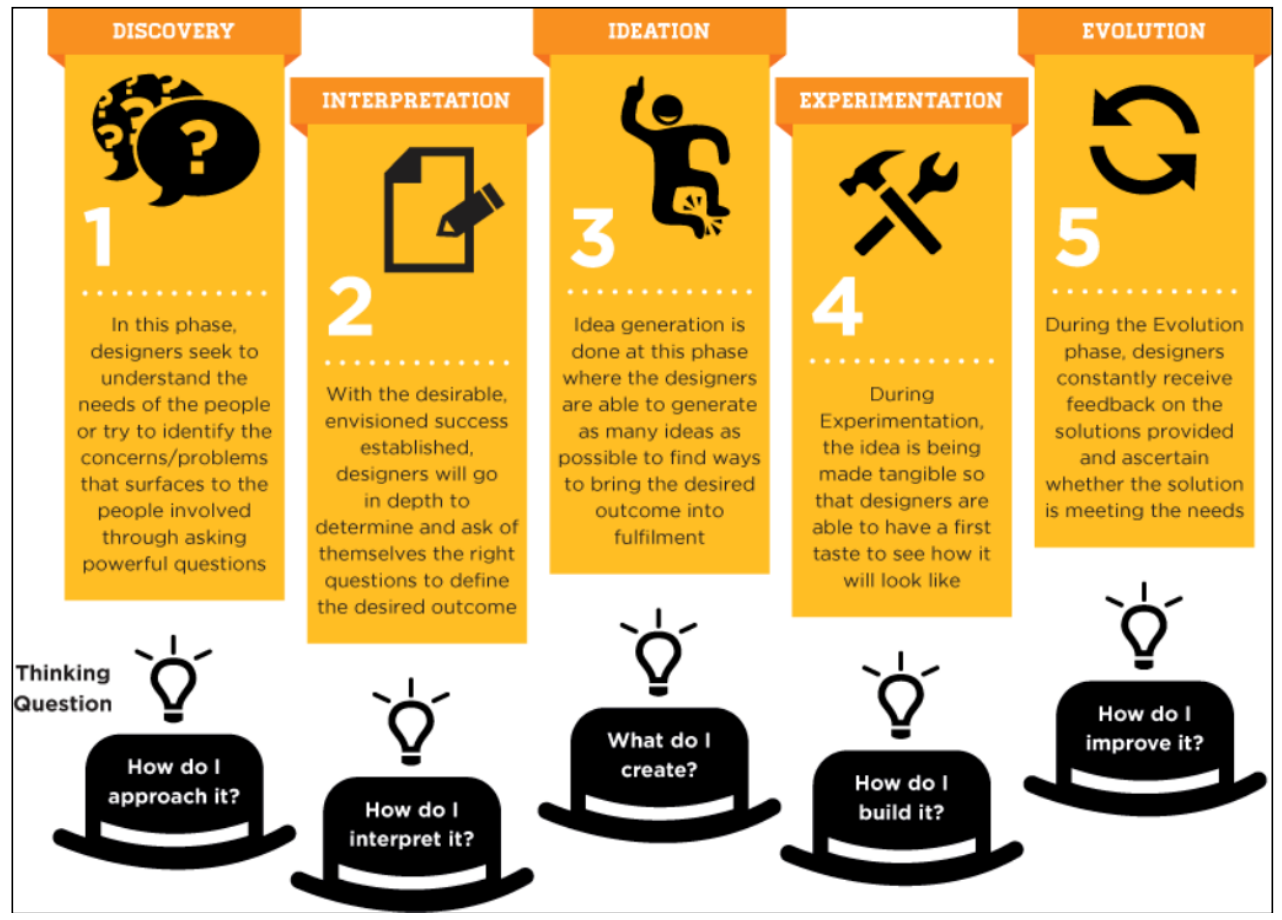

Figur 4: Model for designtankning (bentet fra http:/ / mic.boxiel.com/portfolio/ designthinking)

Gennem sammenkoblingen af designtænkning som didaktisk metode og abduktive læringsdesigns peges der også på, hvordan underviserens udvikling af læringsdesign $i$ sig selv er en abduktiv kritisk-kreativ designproces, hvorigennem undervisningsformatet designes, gen-designes og om-designes, indtil det understøtter og fremmer teknologisk forestillingskraft og handlekraft på værdifulde, relevante og meningsfulde måder. En proces, der som i vores tilfælde, kan tage flere år og mange gennemløb. Når læringsdesign udvikles og læringsdesignets proces udføres, fremkommer begge processer gennem iterative gennemgange af:

- Discovering: Hvordan vi vil gå til projektet? (udforskning af domæne for læringsdesign /designproces)

- Interpreting: Hvordan vi vil forstå det? (opdagelse af potentialer for læringsdesign / designproces)

- Ideating. Hvad vi vil skabe og konstruere? (generering af konkrete ideer, der kan handles på gennem læringsdesign / designproces)

- Experimenting: Hvordan vi vil bygge og udfolde det? (afprøvning af - og forsøg med prototyper)

- Improving: Hvordan vi vil forbedre vores fælles projekt/fortælling gennem iterativ udvikling? (udvikling og forbedring af læringsdesign / objekts to talk with)

Gennem denne kobling af designtænkning og læringsdesign fremkommer abduktive læringsdesign som fleksible og åbne processer, der er målrettet den konkrete læringskontekst og de unikke forhold, der eksisterer i denne. Således bør også udviklingen og praktiseringen af abduktive læringsdesign udtrykke 
design visdom: den rette ting, for de rette folk, på det rette tidspunkt, på det rette sted, på den rette måde, af de rette grunde (Cross, 2011). Abduktive læringsdesign for teknologisk forestillingskraft og handlekraft forudsætter altså en vedvarende dialog mellem designvision (planlægning) og designrealitet (praksis) gennem iterative tilpasninger af læringsdesignet. Således kræver designtænkende læringsdesign $i$ sig selv opøvelsen af udforskende og eksperimenterende tilgange til undervisning, eller hvad der inden for design tænkningen kaldes for 'design inquiry':

"Every design process is a process of inquery, and every enquery is
unique. Design inquery is therefore a process that begins with
unlearning old answers and starting with a new mind or beginner's
mind open to new learning, exciting new possibilities, and
rewarding new insights - in other words, starting with a letting go
[...] They are called to open up to new ideas, new ways of seeing
things, altered directions and surprising outcomes, by letting go of
their previous experience and design solutions". (Nelson \&
Stolterman 2012:242)

Hvis vi ser på "Vejledning for faget dansk" samt de reviderede retningslinjer for K12 uddannelse, kan vi se, hvordan en sådan opøvelse af 'design inquiry' gennem designtænkende læringsdesign, kan klæde underviseren på til den 'teacher inquiry' og 'teacher agency', der er nødvendig for at kunne uddanne til entreprenørskab og innovation: "Lærerne skal nu arbejde systematisk med at designe innovative læreprocesser for eleverne i skolen" og "Der skal nu også være fokus på fagets kreative og skabende elementer. Udfordringen består nu ikke blot $\mathrm{i}$ at undervise om innovation... men i innovative læringsaktiviteter, der har til formål at udvikle elevernes innovationskompetence"2. Vi mener, at abduktive læringsdesign i form af åbne processer med fokus på ideational learning kan lede til læringsdesign for teknologisk forestillingskraft og handlekraft, hvor kritisk-kreativ idegenerering og problemløsning med teknologier bliver mulig.

\section{Brugen af robotter i designtænkende læringsdesign for demokratisk tværfaglig dannelse}

Design visdom i udformningen og praktiseringen af læringsdesign kan understøttes gennem designprocesser af 'reflection-in-action' (Schön, 1983), karakteriseret som 'learning by experience' (Dewey, 1916) og med formålet at fremkalde 'liberatory enterprise' (Freire, 1974). Disse positioner samles i, hvad vi kalder en kritisk-pædagogisk designtænkning, idet den kritiske pædagogik kobles til designtænkning gennem handlekraft som dannelsesideal (Schnack, 1998). Ifølge såvel Schnack som Freire er handlekraft opøvelsen og udøvelsen af dialogisk demokratisk dannelse gennem handlen. Designtænkning som didaktisk metode for teknologisk forestillingskraft og handlekraft må altså ud fra dette perspektiv i sig selv være kritisk refleksiv og dernæst sigte mod uddannelse af kritisk refleksive deltagende medborgere. Således må også designtænkning som didaktisk metode have til formål at uddanne medborgere,

2 Vejledning for faget dansk, afsnit 3.3 
der er i stand til at forholde sig kritisk-refleksivt og medskabende til teknologi i samfundet. For at dette kan ske kræves abduktive læringsdesign, der ud over opøvelsen af teknologisk forestillingskraft og handlekraft $i$ formelle læringskontekster, ydermere sigter mod at fremme kritisk-kreativt medborgerskab i samfundet gennem udøvelse af forestillingskraft og handlekraft gennem teknologier. Dette forhold udmønter sig i didaktisk designtankning som metode for demokratisk dannelse gennem kritisk-kreativ teknologisk forestillingskraft og handlekraft. En sådan metode integrerer og udtrykker Freires begreb om 'education for critical consciousness' i udviklingen og praktiseringen af læringsdesign:

"They could be helped to learn democracy through the exercise of democracy; for that knowledge, above all others, can only be assimilated experientially. More often than not, we have attempted to transfer that knowledge to persons verbally, as if we could give lessons in democracy while regarding popular participation in the exercise of power as 'absurd or immoral'. We lacked - and needed - sufficient courage to discuss with the common man his right to that participation. Nothing threatened the correct development of popular emergence more than an educational practice which failed to offer opportunities for the analysis and debate of problems, or for genuine participation; one which not only did not identify with the trend toward democratization but reinforced our lack of democratic experience". (Freire 1974: 32-33)

Abduktive læringsdesign for teknologisk forestillingskraft og handlekraft forsøger således med et kritisk-kreativt afsæt at give mennesker mulighed for gennem teknologiske processer at opleve og erfare, at problemer i deres hverdag kan forandres og idéer udtrykkes i kraft af deres egen medvirken. Designtænkning som didaktisk metode skal således arbejde for, at mennesker bliver handlende subjekter $\mathrm{i}$ deres eget liv via aktiv medvirken $\mathrm{i}$ undervisning og læring, der udvikler forestillingskraft og handlekraft. I det følgende vil vi beskrive designtænkning som didaktisk metode for teknologisk forestillingskraft og handlekraft gennem den konkrete case, der udgøres af et abduktivt læringsdesign, der anvender LEGO Mindstorm robotter som eksempel. Modulære robotter og robot-teknologi kan, hvis deres potentialer indenfor uddannelse udnyttes, spille en central rolle som teknologisk aktør i læringsdesign for demokratisk dannelse (se også Toft \& Nørgård, 2015 for en dybdegående beskrivelse af anvendelsen af modulære robotteknologier for designtænkning og dannelse). Abduktive læringsdesign, der integrerer robotteknologi gennem designtænkende processer for demokratisk dannelse i freiresk forstand, åbner op for konstruktionen af kritisk-kreative 'objects to talk with' (Mor, 2013), der er såvel samfundsvendte som samfundsengagerede. I sådanne abduktive læringsdesign baseret på kritisk-kreativ didaktik og designtænkning ser vi der opstår en produktiv spænding mellem det divergerende og det konvergerende, det kritiske og det kreative, forestillingskraften og handlekraften, der går på tværs og rækker ud over rent 
fagdidaktiske tilgange til uddannelse og etablerer tværfaglige møder, der sætter fagligheder i spil. En sådan tværfaglig dialog er vigtig, da der indtil videre har været en fremherskende tendens til primært at indtænke nye teknologier som robotter i de såkaldte STEM-orienterede fag (Science, Technology, Engineering og Mathematics), mens de har været så godt som fraværende fra de humanistiske fag (Nørgård \& Paaskesen, 2016; Nørgård \& Brandt, 2016). Et sådant tværfagligt møde ser vi også i nedenstående case, hvor det abduktive læringsdesign Future-Tech-Town Year 2060 integrerer såvel samfundsfag (sociologisk og kritisk tænkning), dansk (historiefortælling, kommunikation og samarbejde) og digital dannelse (teknologisk begrebsanvendelse og ordforråd) såvel som mere STEM orienterede fagligheder. Det abduktive læringsdesign udfolder sig som en proces, hvor de lærende er engagerede i udforskning af eksperimenter med modulær robotteknologi, hardware- og softwaredel, lyd, sensorer, programmeringsflade, -blokke og programmeringspalette, og således erhverver de lærende et fundament for indsigt $i$ og anvendelse af robotteknologi (basic \& applied learning; Dettmer, 2005). Denne indsigt i - og anvendelse af robotteknologi opstår gennem engagement $i$ autentiske verdensvendte tematikker og projekter $\mathrm{i}$ form af kritisk-kreative teknologiske forestillinger om fremtidens samfund og den rolle, robotteknologien kan spille heri. Gennem opbygningen af en reflekteret designvision for samfundet, der kommer til udtryk som designrealitet gennem teknologiske handlinger, udforskes robotteknologiske tilgange til - og fagligt engagement $i$ bl.a. ressourcespild, strømforsyning og -forbrug, genbrug mm. I det abduktive læringsdesign mødes STEM-baserede kompetencer med demokratisk dannelse som et kritisk-refleksivt teknologisk engagement med reelle problemstillinger (konvergent designtænkning) og fremtidsvendte forestillinger (divergent designtænkning). Abduktive læringsdesign som Fututure-Tech-Town Year 2060 faciliterer en divergerende og konvergerende designproces med modulære robotteknologier, hvor læring kommer til udtryk som en dialektik mellem udforskende, opdagende og idegenererende teknologisk forestillingskraft og afprøvende, udviklende og prototypefremstillende teknologisk handlekraft i forhold til konkrete problemstillinger i samfundet såsom fremtidens robotteknologiske samfund og dets potentialer og problematikker. Hvad vores mangeårige undervisningspraksis og forskning $i$ opøvelse af teknologisk forestillingskraft og handlekraft har vist os er, at teknologi såsom robotter, $3 \mathrm{~d}$ printere, programmérbare kredsløb eller programmeringssprog må bringes i anvendelse i formelle læringskontekster på måder, der ikke blot sigter mod informationstilegnelse eller anvendelsesfærdigheder, men mod 'ideational learning' og kritisk-kreativ teknologisk dannelse. Dette gælder ikke kun i STEM-orienterede fagligheder, men i særdeleshed også i den humanistiske undervisning, hvis fremmedgjortheden, utrygheden og overfladekendskab omkring robotters væren og gøren skal transformeres til kritisk-kreativ teknologisk forestillingskraft og handlekraft (Nørgård \& Paaskesen, 2016; Nørgård \& Brandt, 2016; Nørgård \& Charlton). Designtænkning som didaktisk metode fordrer således en tilgang til teknologi i uddannelsessystemet, hvor underviseren inviterer til, understøtter og fremmer teknologisk viden, gøren og væren på abduktive måder. Gennem abduktive læringsdesign for demokratisk dannelse arbejdes der med at forvandle robotter fra at være en fremmedgørende mekanik, man skal have viden om, og programmérbar 
teknologi man skal have færdigheder i, til at være teknologi hvorigennem man kan udtrykke sine forestillinger og tanker gennem udforskende og eksperimenterende handlinger. Teknologier tilgås således som et menneskeligt udtryksmiddel snarere end som teknologisk objekt. Modulær robotteknologi i Future-Tech-Town Year 2060 er altså noget, man på en gang skildrer fabulerende teknologifortællinger med, fremsætter reflekterede fremtidsvisioner med og lærer at mestre og konstruere med gennem designprocesser. Sådanne abduktive teknologiske processer med robotter har således også potentialer til at åbne op for filosofiske samtaler omkring fremtidens samfund, teknologiske værens- og udtryksformer, samt hvad det vil sige at være menneske og teknologi. Herigennem opstår teknologisk forestillingskraft og handlekraft på en og samme tid som robot-læring, robot-design, robot-didaktik og robot-etik. Undervisere og studerende mødes i rollen som kritisk-kreative samfundsborgere, der dialogisk og designtænkende engagerer sig i samfundsmæssige problemstillinger gennem abduktive læringsdesign med teknologier. Et engagement der kræver såvel divergent idegenerering som konvergent problemløsning. Hvad, der er i centrum, er hverken teknologiske fakta eller færdigheder, men den dialog, kreativitet og kritiske refleksion, der opstår i dette møde. Et møde, hvor underviser og studerende gennem designprocesser kritisk-kreativt engagerer sig i teknologiens tænken, væren og gøren, der har et iboende potentiale for at nå toppen af Blooms reviderede taksonomi på en måde, der får det 21. århundredes kompetencer til at fremtræde som værdifulde og meningsgivende dybdestrukturer - som 'ideational learning'. Designtænkning som didaktisk metode for teknologisk forestillingskraft og handlekraft gennem abduktive læringsdesign for demokratisk dannelse er således overordnet kendetegnet ved:

1. at være udformet som iterative didaktiske designprocesser, der inviterer til, understøtter og fremmer divergent og konvergent designtænkning

2. at tage form som åbne dialogiske og demokratiske lærings- og undervisningsformater uden fastlagte mål og produkter men stadig med klare formål, der bygger på multiple løsningsmuligheder og åbenhed i forhold til designvisioner, designvalg og designrealiteter

3. at give tid til kritisk-kreativt at udforske, afprøve og udforske ideer og problemer gennem abduktive læringdesign i modsætning til informerende, produkt-fastlagte, færdighedsskabende eller trinvise teknologiske processer

4. sigter mod demokratisk dialog, refleksiv samskabelse og kritisk-kreativ tænkning på baggrund af en fælles divergerende-konvergerende designproces, der leder frem mod udviklingen af en samlende udfoldet designvision, der kommer til live som reflekteret designrealitet, der præsenteres og gentænkes på tværs af grupper og fællesskaber

Abduktive læringsdesign udfolder sig altså som en emergerende proces, der dukker frem fra teknologierne mellem hænderne og dialogerne mellem teknologierne. Det er ikke et læringsdesign, der er færdigt før undervisningen går i gang, og hvis afslutning og udkomme kendes på forhånd. Det er derimod et læringsdesign, der opstår i dialektikken mellem divergerende og konvergerende bevægelser, mellem designvision og designrealitet, mellem underviser og studerende, mellem forestillingskraft og handlekraft og mellem 
on-floor og on-screen udforskninger og afprøvninger. Gennem designtænkning som didaktisk metode for demokratisk dannelse skabes en atmosfære og praksis ud fra en forståelse af at "People don't get ideas; they make them" (Resnick, 1998, s. 3). Noget, der kræver opøvelsen af abduktive og kritisk-kreative tilgange til teknologier. Eller hvad vi her har kaldt for designtænkning som didaktisk metode for teknologisk forestillingskraft og handlekraft, der sigter mod demokratisk dannelse.

\section{Future-Tech-Town Year 2060 som eksemplarisk case for designtænkning som didaktisk metode}

Følgende case præsenterer et eksempel på et abduktivt læringsdesign for demokratisk dannelse gennem teknologisk forestillingskraft og handlekraft. Læringsdesignet Future-Tech-Town Year 2060 demonstrerer, hvorledes der kan arbejdes med robotteknologi i formel uddannelse gennem abduktive designprocesser. I Future-Tech-Town Year 2060 anvendes LEGO Mindstorm robotteknologi $i$ et fagdidaktisk kreativt-teknologisk projekt $i$ formel uddannelse i udskolingen. I dette tilfælde gøres der brug af tværfaglige

elementer fra fagene samfundsfag, dansk, IT og teknologi og naturvidenskabelige fag. I nedenstående fremstillede og udfoldede læringsdesign vises, hvordan designprocesser og abduktiv tænkning integreres i læringsdesignet på måder, der sigter efter 'ideational learning' (Dettmer, 2005). Undervisere kan således anvende nedenstående case som afsæt for egne abduktive læringsdesign, da læringsdesign også i sig selv udvikles gennem iterative designprocesser.

I Future-Tech-Town Year 2060 arbejder underviser og studerende med nye teknologier såsom LEGO EV3 Mindstorm robotter for at indarbejde tanke- og handle-rutiner, som leder til en dybere forståelse (i konteksten) af robotters funktioner, potentialer, virke og adfærd (basic \& applied learning). Denne tilegnelse foregår for at kunne idégenerere og konstruere en fælles fremtidsvision for, hvordan robotteknologi kan indgå i - og spille sammen med samfundet i år 2060 (ideational learning). På den måde arbejdes der på lavereordens læringsniveauer for at kunne anvende robotteknologi til at de studerende kan udtrykke deres teknologiske forestillingskraft og fremsætte en kritiskrefleksiv stillingtagen i deres historiefortælling ved at arbejde designorienteret med at tænke, gøre og være med robotteknologi. Lavere-ordens læringsniveauer er således ikke mål eller trinmål i sig selv, men noget der opstår i en kritisk-kreativ teknologipraksis, der er fokuseret på at understøtte og fremme højere-ordens ideational learning. Viden og færdigheder opsøges og erhverves for at kunne arbejde handlekraftigt med at fremsætte sin forestilling om fremtidens samfund gennem anvendelse af teknologier.

LEGO EV3 Mindstorm er en forholdsvis avanceret og åben robotteknologi, der har sensorer, således at robotten kan interagere formålsbestemt $\mathrm{i}$ forhold til sansning af omgivelser og måder, hvorpå den er programmeret til at reagere. Mindstorm er således en åben modulær robotteknologi, der qua denne udformning kalder på cyklusser af teknologisk forestillingskraft gennem eksplorative og eksperimenterende handlinger (Nørgård \& Paaskesen, 2016, s. 15-16). Mindstorm kan som åben modulær robotteknologi dernæst bringes i anvendelse i abduktive læringsdesign centreret omkring underviserens og den studerendes udforskning, konstruktion og 
eksperimentering gennem divergerende og konvergerende designprocesser, hvor idéer udformes og problemer løses i dialog med hinanden, teknologien og læringskonteksten. Teknologi og proces rammesættes som åben for forskelligartede designvisioner, der gennem iterative designprocesser i vekselvirkning mellem 'on-screen' og 'on-floor' aktiviteter manifesterer sig som designrealitet, der udtrykker mere eller mindre design visdom.

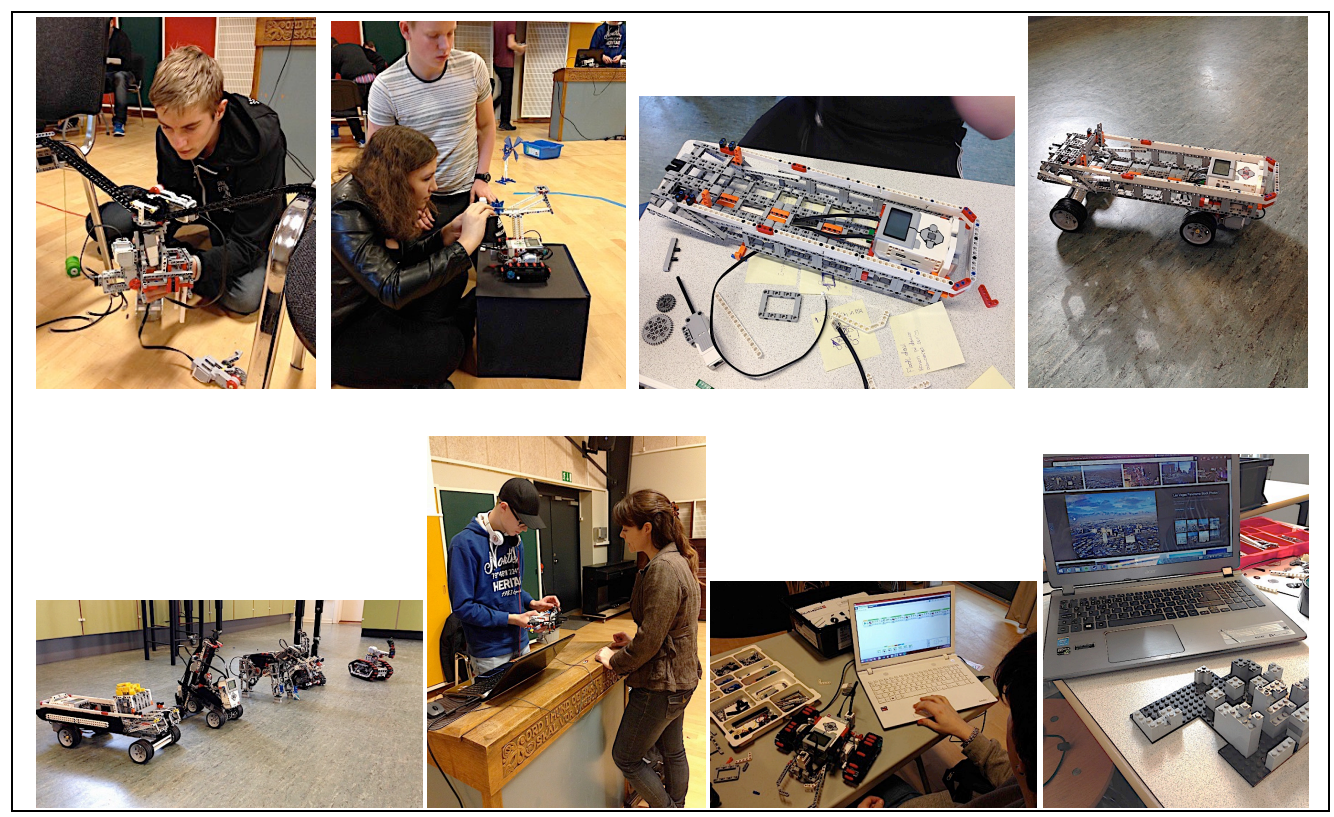

Figur 5: Billeder fra gennemlobet af Future-Tech-Town Year 2060,bvor elever arbejder designtankende med robotter med det formål at konstruere, kode og fortalle historier om fremtidens samfund med robotter (Billeder af Rikke Berggreen Paaskesen).

Future-Tech-Town Year 2060 er et fagdidaktisk abduktivt læringsdesign, der forløber i iterative designcyklusser over to dage. Forløbet er gennemført $\mathrm{i}$ et samarbejde mellem Klank Efterskole og Skannerup Efterskole i år 2015/2016, udviklet af Rikke Berggreen Paaskesen og gennemført af Rikke Berggreen Paaskesen og Jens Andersen-Mølgaard. Grupperne af 16-17 årige elever (studerende) skulle $\mathrm{i}$ forløbet forholde sig til et abstrakt fremtidsscenarie (en fremtidsby $i$ år 2060), hvorudfra de skulle idégenerere omkring, hvorledes robotteknologi kunne tænkes at have indflydelse på menneskers hverdagsliv i et samfund anno 2060. Selve læringsdesignet var udformet som et iterativt gennemløb af designprocessens faser (figur 4), hvor hver fase var struktureret omkring en række åbne spørgsmål, der sigtede mod at bevæge undervisningen hen imod ideational learning. Det vil sige, at underviser og studerende (elever) gennem kritisk-kreative designargumenter begrundede såvel forestillinger som handlinger. Ligesom underviser og studerende dialektisk bevægede sig mellem divergente designvisioner til konvergent designrealitet $\mathrm{i}$ iterative cykler gennem udforskning, opdagelse, idegenerering, afprøvning og udvikling.

Discovery: De studerende samtaler i grupper omkring, hvor de kan forestille sig, robotteknologien har en positiv indflydelse på mennesket i et fremtidssamfund, og hvor den kan tænkes at fremstå som en trussel for mennesket. Her udforsker de studerende designdomænet gennem alt fra filmiske oplevelser, egne forestillinger, brug af nettet samt lærers 
introducerende oplæg omkring robotteknologi i samfundet. Gennem divergente designprocesser findes mulige svar (designvisioner) på spørgsmålet 'Hvordan vil vi gå til projektet?'

Interpretation: Dialog og udforskning ud fra ovennævnte spørgsmål leder dernæst de studerende til overvejelser og tolkninger omkring bl.a. hvilke køretøjer, der mon er i et fremtidigt bysamfund. Hvorledes ser køretøjerne ud, og hvorledes skal de bygges og designes til at have en praktisk funktion $i$ historiefortællingen? Har folk i Future-Tech-Town for eksempel blind tillid til førerløse biler? Gennem fremstillingen af en fælles designvision fortolkes designdomænet og et svar på 'Hvordan vil vi forstå det?' dukker op som noget, der kan handles på (designhandlinger).

Ideation: De studerende idégenererer dernæst omkring hvilke køretøjer og hvilke mennesker, der har hvilken funktion i samfundet som henholdsvis de gode og de onde (en trussel). De skitserer, designer og får ideer til, hvordan de kan programmere deres robot, så den kan udføre sin rolle i det fælles projekt. De studerendes udtryk for det gode bliver her i form af en gruppe surfere (mennesker), som repræsenterer de gode væsener i fortællingen, der skal reddes fra trusler i samfundet. En vindmølle repræsenterer byens kraftværk, en base, hvorfra der leveres elektricitet til byen. Energibiler, som på bæredygtig vis bidrager med strøm til byen, skal også reddes. Den konvergerende designvision manifesterer sig således i en række konkrete idéer, der kan afprøves. Gennem divergent designtænkning idégeneres der frem mod de forestillinger (designforslag), der skal afprøves i praksis for at finde svaret på hvilken idé, der specifikt skal konstrueres.

Experimentation: De studerende afprøver deres robotter og bruger god tid på at iterere programmeringen af robotten, så den kan udføre sin funktion i det fælles projekt på den bedste måde. Der diskuteres, argumenteres, afprøves, eksperimenteres og samskabes. De studerende forholder sig nu også til, hvorledes den fælles fortælling, fællesskab og socialt liv, hverdagsliv og fritidsliv udfolder sig i et fremtidigt teknologisk samfund omkring robotten. Hvilke teknologier vil dominere civilt liv i samfundet og hvilke slags services vil der være? Hvem er reddere og hjælpere? Der bygges og designes rullemarier, som kan samle bomber op for at beskytte det gode i samfundet. To selvdesignede satellitter skal kommunikere og transmittere tv-signal til en tv-bil. En tankbot med en selvdesignet klo og en selvdesignet fjendtlig robot, der inkarnerer det onde, affyrer bomber som en trussel. En robot får påsat et lille kamera og er således byens fotobil, der overvåger og rapporterer om byens tilstande. Alle robotterne $i$ det fælles scenarie har deres egen rolle og mission i det fælles projekt. Der afprøves prototyper og afprøves forskellige programmeringer i en bevægelse fra det divergente mod det konvergente $\mathrm{i}$ arbejdet frem mod eksternaliseringen af den endelige idé (designrealitet). I centrum er 'objects to talk with', eftersom samtalerne om fremtidens samfund - dets struktur, funktionalitet, værdier og meninger - cirkulerer omkring robotterne i et forsøg på gennem afprøvninger og tests at få bedre greb om forestillingen, fortællingen og de relevante designhandlinger. 
Evolution: Grupperne er nu klar til at fremvise, demonstrere, fortælle og indgå i diskussioner omkring den funktion, deres individuelle robot har i det fælles skabte projekt, som er Future-Tech-Town Year 2060. Alle lytter til hinandens fremstilling af deres teknologiske forestillinger og handlinger samt hvilken kraft, de giver til den fælles historiefortælling (designargument), og alle afprøver nu at koordinere såvel robotternes kørsel og funktioner med tilhørende scenariefortælling. Som en afsluttende refleksion på dette første fælles iterative forløb af læringsdesignet, bliver undervisere og studerende enige om, at det abduktive læringsdesign til næste forløb (anden iteration) skal redesignes, så der lægges endnu mere vægt på at udtrykke teknologisk forestillingskraft og handlekraft gennem kritisk-kreative designargumenter, hvorledes vi sammen i robottens funktion og den fælles fortælling kan gøre Future-Tech-Town til et bedre sted at leve og at arbejde.

Underviser gen-designer på baggrund af evaluering af læreproces og læringsdesign efterfølgende designet til bedre at kunne forløse dets formål ved at integrere nye forhindringer og udfordringer, som eleverne skal medtænke og forholde sig til i henholdsvis robottens adfærd og funktion (programmering) som $\mathrm{i}$ historiefortælling $\mathrm{i}$ næste iteration af læringsdesignet. Underviser og studerende er således samskabere af læringsdesign, designproces og designargument. Nye spørgsmål, forestillinger og forundringer opstår: Hvad hvis der kommer hav-robotter og forstyrrer surferne (der er indtænkt $i$ scenariet) på vandet? Hvordan ved man, om en drone-robot er med os eller mod os? I dialogisk samskabelse mellem underviser og studerende arbejdes der også på det didaktiske handleplan designorienteret, idet såvel underviser som studerende er designere af læreproces og læringsdesign (Laurillard, 2012).

Eleverne udforsker, idégenererer, afprøver og diskuterer i grupper gennem designtænkningens faser discovery, interpretation, ideation, experimentation \& evolution (figur 3) med såvel samfundsfortælling som robotkonstruktion og -programmering frem mod et fælles fremtidsdesign. Underviser og studerende indgår i dialogiske, samskabende og faciliterende teknologiske processer, der har 'zonen for nærmeste udvikling' (Vygotski, 1978) for øje. Således fungerer underviseren i rollen som faciliterende samtalende medskaber, der gennem 'teacher agency' (Priestley, Biesta \& Robinson, 2015; Laurillard, 2008) sikrer, at de forskellige gruppers teknologiske forestillinger og handlinger koordineres og bringes sammen $i$ en fælles designvision og designrealisering, som sammenlagt fremstår som et designargument for et fremtidssamfund. Underviserens rolle er bl.a. at kvalificere og udfordre såvel de enkelte gruppers kritisk-kreative arbejde med robotteknologien, deres argumentation omkring dette arbejde - samt stillingtagen til hvordan de faglige og sociale problemstillinger kommer til udtryk i det fælles scenarie, der dukker frem som de studerendes bud på den ordnede problemstilling: "Hvordan påvirker og forandrer robotteknologier menneskers hverdagsliv i et fremtidigt samfund?". 


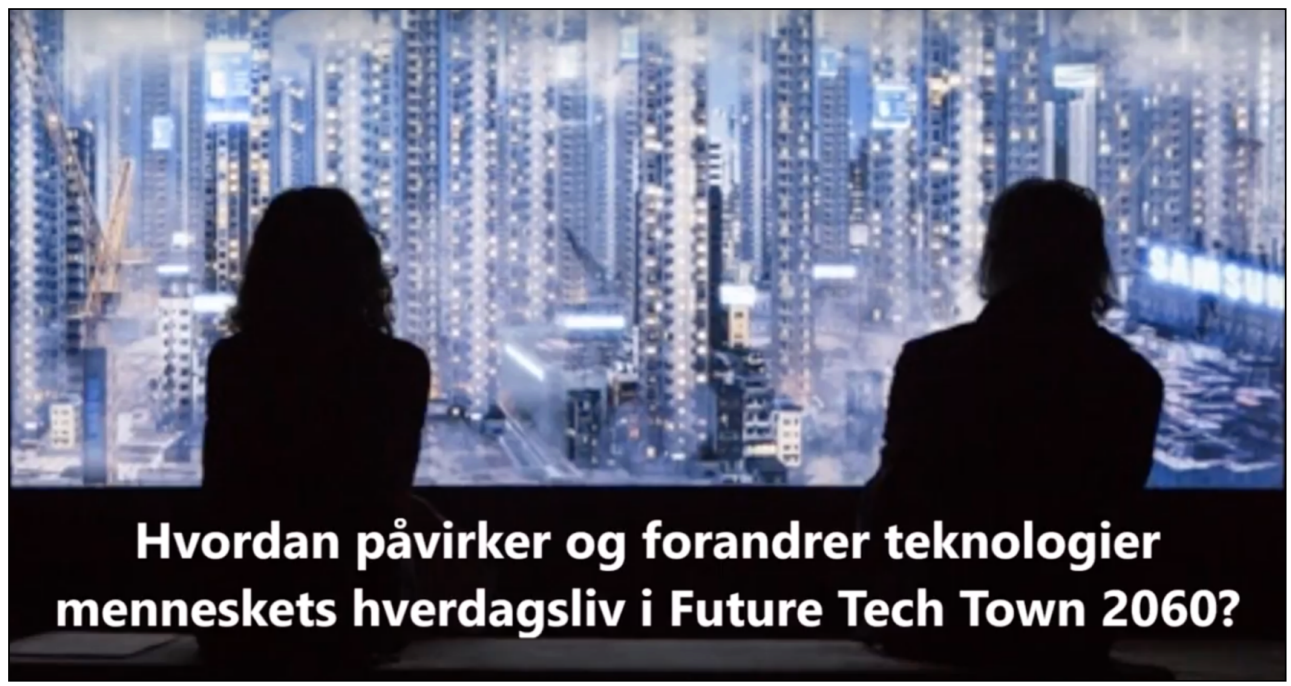

Figur 6: Video fra

bttps:/ / www.youtube.com/watch? $v=Z g 7 N f 27 L r D A \& l i s t=P L Y o U z W 5 G h C p N C n v B i 4 G U i 5 L Y \_c 8 s C a r G 1$ Stillbillede fra videoen Mindstorm på Klank. Efterskole og Skannerup Efterskole v.2 af Jens Andersen-Molgaard, der giver indblik $i$ - og fremviser elevernes designproces, mens de arbejder sig frem mod deres bud på, hvordan robotteknologier influerer og forandrer mennesker hverdagsliv $i$ et fremtidigt samfund.

\section{Konklusion: Fremtids-skabelse med designtænkning som}

\section{didaktisk metode}

Vi har gennem vores praksis og forskning fundet, at designtænkning som didaktisk metode for teknologisk forestillingskraft og handlekraft, som oven for beskrevet, er en velegnet model for udviklingen af abduktive læringsdesign, der gennem konvergente og divergente designprocesser understøtter og fremmer underviseres og studerendes innovationskompetence gennem ideational learning med teknologier. Designtænkningens iterative processer koblet med didaktisk tænkning og handlekompetence for demokratisk dannelse og teknologisk forestillingskraft udgør åbne undervisnings- og læringskontekster, der har potentiale til at sigte mod tilegnelse og udfoldelse af kritisk-kreativt medborgerskab gennem dialogisk deltagelse, der pro-aktivt forholder sig til og forandrer de udfordringer, man støder på i egen livsverden og i det omgivende samfund. Designtænkning som didaktisk metode og abduktive læringsdesign har i kombination med hinanden potentiale til at medføre teknologisk kulturel forandring i såvel attitude, tilgang og praksis hos uddannere, undervisere, studerende og elever for så vidt angår deres teknologianvendelse i formelle læringskontekster.

Tilgang, set-up og indhold $\mathrm{i}$ et arbejde med fremtidsskabelse gennem designtænkende læringsdesign for demokratisk dannelse styrker såvel elevernes individuelle robusthed som deres almene dannelse til fremtidigt medborgerskab, idet de gennem sådanne processer og designs har mulighed for at opøve evnen til at udføre hvad Nelson \& Stolterman (2012) kalder intentional change in an unpredictable world, når de stilles over for udfordringer $\mathrm{i}$ deres livsverden eller i samfundet. Gennem udførslen af designvisioner, designrealiseringer og designargumenter med teknologier på baggrund af abduktive læringsdesign opstår en kritisk refleksion omkring problemstillinger og muligheder i verden. Denne kritiske refleksion bringes dernæst i hands-on anvendelse og $i$ dialog med omverdenen gennem designprocessers 
eksternalisering af designvisioner og materialisering af designargumenter, sådan at en iterativ abduktiv læringscyklus opstår. Ud fra denne abduktive læringscyklus opstår muligheden for design visdom og innovation (ideational learning) i form af reflekteret fremtids-skabelse og problem-løsning gennem refleksive dialoger (Schön, 1987) mellem designvisioner og designrealiteter, der har overførselsværdi til senere i deres liv, når de - og vi som samfund - står overfor ukendte fremtider og problemer.

Set $\mathrm{i}$ et større samfundsperspektiv sigter designtænkning som didaktisk metode mod at understøtte og fremme underviseres og studerendes evne til at forholde sig såvel kritisk problemløsende (konvergent designtænkning/handlekraft) som etisk fortællende (divergent designtænkning/forestillingskraft) til (robot)teknologiers indtog i samfund og i livsverden. Gennem abduktive læringsdesign muliggøres åbne processer med samfundsvendt og samfundsengagerende potentiale, hvor undervisere og studerende gennem teknologisk forestillingskraft og handlekraft forholder sig kreativt, nytænkende og konstruktivt til samfundets udvikling. Det forudsætter dog en uddannelsesmæssig og en dannelsesmæssig teknologisk kulturel forandring, hvor informationstransmitterende ('banking model of education'), færdighedsopbyggende (digital dannelse) og produktions-orienterede ('key chain syndrome') læringsdesign, der lærer om og oplærer i teknologianvendelse, erstattes af åbne abduktive læringsdesign for ideational learning. Det er ikke tilstrækkeligt at uddanne informationsoplyste eller produktproducerende borgere. Mindst lige så vigtigt er det at uddanne kritisk-kreative udforskende, afprøvende, idégenererende og eksperimenterende borgere gennem abduktive iterative læringscyklusser, der sigter mod højere-ordens teknologisk forestillingskraft og handlekraft.

Læringsdesign, der tager designtænkning som didaktisk metode for demokratisk dannelse, har affinitet med Wolfgang Klafkis refleksivekonstruktive didaktik, som er kritisk og samfundspolitisk orienteret. Klafki (1996) er fortaler for et dannelsesbegreb, som er 'tidssvarende og fremtidsorienteret', hvor målet er en øget bevidsthed omkring vores samfundsmæssige problemstillinger: "Min grundtese lyder: Almendannelse er i denne henseende ensbetydende med at få en historisk formidlet bevidsthed om centrale problemstillinger i samtiden og - så vidt det er forudsigeligt - i fremtiden at opnå den indsigt, at alle er medansvarlige for sådanne problemstillinger, og at opnå en beredvillighed til at medvirke til disse problemers løsning" (Klafki, 1996, s. 74). Hvis vi i uddannelse vil tilstræbe at (ud)danne til - samt at fremme kvaliteter som kritisk-kreativ innovation og dialogisk deltagelseskultur, så forudsætter det læringsdesign og pædagogiske tilgange, som også i deres teknologianvendelse og -inddragelse kan understøtte og fremme disse kvaliteter. Her ser vi abduktive læringsdesign for demokratisk dannelse som en metode for underviseren til på værdifuld, meningsfuld og relevant vis at udvikle og videreudvikle sin praksis gennem iterative divergente og konvergente designprocesser i kombination med inddragelse af ny teknologi $i$ undervisningen: ".. the purpose of education is empowerment and emancipation for future citizenship. Hence, the teacher cannot transmit knowledge, lead the way, or instruct the students about what they need to know in order to live and learn in the $21_{\text {st }}$ century. They need to go there 
together" (Nørgård \& Paaskesen, 2016, s. 11). Teknologisk forestillingskraft og handlekraft forudsætter således, at vi tør bevæge os på udforskende og eksperimenterende læringseventyr sammen. Og det forudsætter åbne modulære teknologier bragt $\mathrm{i}$ anvendelse $\mathrm{i}$ åbne abduktive læringsdesigns inden for åbne eksplorative og eksperimenterende uddannelsessystemer, som sigter mod højere-ordens læring og uddannelse af kritisk-kreative samfundsborgere, der besidder såvel teknologisk forestillingskraft som handlekraft.

\section{Referencer}

Aaen, J. \& Nørgård, R.T. (2015). Participatory academic communities: A transdiciplinary perspective on participation in educationa beyond the institution. Conjunctions. Transdiciplinary Journal of Cultural Participation Vol 2, No 2, s. 67-98.

Anderson, L.W. \& Kratwohl, D.R. (Eds.) (2001). A taxonomy for learning, teaching, and assessing: A revision of Bloom's taxonomy of educational objectives. New York: Longman.

Anderson, T. \& Shattuck, J. (2012). Design-Based Research: a decade of progress in education research? Educational Researcher, Vol 41, No 1, s. 16-25.

Balsamo, A. (2011). Designing culture - the technological imagination at work. Duke University Press.

Bear J. (2013). Teaching for Creativity. Domains and divergent thinking, intrinsic motivation, and evaluation. In: Teaching creatively and teaching for creativity. Eds. M.B. Gregerson, H.T. Snyder and J.C. Kaufman (eds.). London: Springer, s. $175-181$.

Biesta, G., Priestley, M. \& Robinson, S. (2015). The role of beliefs in teacher agency. Teachers and Teaching, Vol 21, No 6, s. 624-640.

Blikstein, P. (2013). Digital fabrication and 'making' in education: The democratization of education. In: Walter-Hermann, J. \& Büching, C. (Eds.). FabLab: Of Machines, makers, and inventors. Bielefeld: transcript Verlag, s. 203222.

Cobb, P., Confrey, J., deSessa, A., Lehrer, R. \& Schauble, L. (2003). Design experiments in educational research. Educational Researcher, Vol 32, No 1, s. 913.

Collins, A., Joseph, D. \& Bielaczyc, K. (2009). Design research - theoretical and methodological issues. Journal of the Learning Sciences, Vol 13, No 1, s. 15-42.

Conole, G. (2013). Designing for Learning in an Open World. London: Springer.

Conole, G., Dyke, M., Oliver, M. \& Seale, J. (2004). Mapping pedagogy and tools for effective learning design. Computers \& Education, Vol 43, s. 17-33. 
Craft, A., Cremin, T., Hay, P. \& Clack, J. (2014). Creative primary schools: Developing and maintaining a pedagogy for creativity. Ethnography and Education 9(1), pp. 16-34.

Cross, N. (2011). Design Thinking. London: Bloomsbury.

Dalziel, J., Conole, G., Wills, S., Walker, S., Bennett, S., Dobozy, E., Cameron, L., Badilescu-Buga, E., Bower, M. (2016).The Larnaca Declaration on Learning Design. Journal of Interactive Media in Education, 2016 Vol. 1, No. 7, s. 1-24.

Daniels, S. (2013). Facilitating creativity in the classroom. Professional development for K12 teachers. In: Teaching creatively and teaching for creativity. Eds. M.B. Gregerson, H.T. Snyder and J.C. Kaufman (eds.). London: Springer, s. 314.

Dewey, J. (2005; 1916). Demokrati og uddannelse. Forlaget Klim.

Edelson, D. C. (2009). Design research: what we learn when we engage in design. Journal of the Learning Sciences, Vol 11, No 1, s. 105-121.

Ertmer, P.A., Parisio, M.L. \& Wardak, D. (2013). The practice of educational/Instructional Design. In: R. Luckin, P. Goodyear, B. Grabowski, S. Puntambekar, N. Winters \& J. Underwood (Eds.): Handbook of design in educational technology. New York, NY: Routledge, s. 5-19.

Florida, R. (2012). The rise of the creative class revisited. New York: Basic Books. Freire, P. (1974). Education for Critical Consciousness. London: Bloomsbury.

Goodyear, P. (2005). Educational design and networked learning: Patterns, pattern language and design practice. Australasian Journal of Educational Technology, Vol 21, No 1, s. 82-101.

Gregerson, M.B., Snyder, H.T. \& Kaufman, J.C. (2013). Teaching creatively and teaching creativity. New York: Springer.

Guskey, T. R. (2002). Professional Develoment and Teacher Change. Teachers and Teaching, Vol. 8, No 3, s. 381-391.

Holmberg, J. (2014). Studying the process of educational design - revisiting Schön and making a case for reflective design-based research on teachers 'conversations with situations'. Technology, Pedagogy and Education, Vol. 23, No. 3, s.1-18.

Klafki, W. (1996; 2001). Dannelsesteori og didaktik - nye studier. Forlaget Klim.

Knobel, M. \& Lankshear, C. (2015). Language, creativity and remix. I: R. Jones (ed), Routledge Handbook of Language and Creativity. London: Routledge. 
Kwon, O. N., Park, J. S. \& Park, J. H. (2006). Cultivating divergent thinking in mathematics through an open-ended approach. Asia Pacific Education Review, Vol. 7, No. 1, p. 51-61.

Laurrilard, D. (2012). Teaching as Design Science - building pedagogical patterns for learning and technology. London: Routledge.

Laurillard, D. (2008). Technology enhanced learning as a tool for pedagogical innovation. Journal of Philosophy of Education, Vol. 42, s. 521-533.

Maina M., Craft B. \& Mor, Y. (Eds.) (2015). The Art \& Science Of Learning Design. Sense Publishers.

Martinez, S. L. \& Stager, G. (2013). Invent to Learn - making, tinkering, and engineering in the classroom. Constructing Modern Knowledge Press.

Mor, Y. (2013). SNaP! Re-using, sharing and communicating designs and design knowledge using scenarios, narratives and patterns. In: Luckin, Rosemary; Puntambekar, Sadhana; Goodyear, Peter; Grabowski, Barbara L.; Underwood, Joshua and Winters, Niall eds. Handbook of Design in Educational Technology. London: Routledge, s. 189-200.

Mor, Y. \& Craft, B. (2012). Learning Design: reflections on a snapshot of the current landscape. Research in Learning Technology, Vol. 20, s. 85-94.

Negus, K. \& Pickering, M. (2004). Creativity, communication and cultural value. London: Sage.

Nelson, H.G. \& Stolterman, E. (2012). The Design Way: Intentional change in an unpredictable world. Cambridge: The MIT Press.

Nørgård, R.T. (2015). Educational Design Thinking: On overcoming present tensions between educators and designers in design processes with new technologies within educational settings. Conference paper for Ethnography and Education Conference, 21-23 September 2015. New College, Oxford University.

Nørgård, R.T. \& Brandt, C. (2016). Technological imagination and divergent design thinking in the educational design studio beyond STEM. Conference paper for Ethnography and Education Conference, 19-21 September 2016, New College, Oxford University.

Nørgård, R.T. \& Charlton, P. (2016). Convention be damned, let learning emerge. On the power of 'learning with.' Conference paper for Ethnography and Education Conference, 19-21 September 2016, New College, Oxford University.

Nørgård, R.T. \& Paaskesen, R.B. (2016). Open-ended education: How open-endedness might foster and promote technological imagination, 
enterprising and participation in education. Conjunctions: Transdiciplinary journal of cultural participation, Vol 3, No 1, s.1-25.

Paaskesen, R.B. (2015). Læring og dannelse i et entreprenørielt perspektiv. folkeskolen.dk

Paaskesen, R.B. (2016). Robotteknologiens indtog og humanioras etiske udfordring. Kristeligt Dagblad Debat.

Papert, S. (1980). Mindstorms. New York: Basic Books.

Papert, S. (2000). What's the big idea? Toward a pedagogy of idea power. IBM Systems Journal, Vol 39, No 3\&4.

Peppler, K., Halverson, E. R. \& Kafai, Y. (2016a). Makeology - makerspaces as learning environments. London: Routledge.

Peppler, K., Halverson, E. R. \& Kafai, Y. (2016b). Makeology - makers as learners. London: Routledge.

Poore, M. (2011). Digital literacy: human flourishing and collective intelligence in a knowledge society. Literacy Learning: The middle years, Vol 19, No 2, s. 20-26.

Priestley, M., Biesta, G. \& Robinson, S. (2015). Teacher Agency - an ecological approach. London: Bloomsbury.

Resnick, M. 1998: Technologies for lifelong kindergarten. Educational Research \& Development. Vol. 46, No. 4, s. 1-18.

Resnick, M. (2007). All I really want to know (about creative thinking) I learned (by studying how children learn) in kindergarten. Proceedings of the $\sigma_{t h}$ ACM SIGCHI Conference on Creativity and Cognition (C\&C'07). ACM, New York, s. $1-6$.

Sawyer, R.K. (2006). Educating for Innovation. Thinking Skills and Creativity, 1, s. 41-48.

Sawyer, R.K. (2012). Explaining creativity: the science of human innovation. Oxford: Oxford University Press.

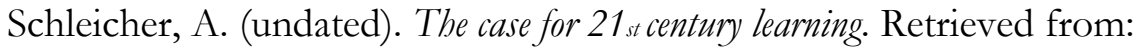
http://www.oecd.org/general/thecasefor21st-centurylearning.htm.

Schnack, K. (1998). Handlekompetence. I: Bisgaard, N.J. (red.) Padagogiske teorier. Billesø \& Baltzer.

Schulman, L. S. (2005a). Signature pedagogies in the professions. Daedalus, Vol. 134, No 3, s. 52-59. 
Schön, D. (2013; 1987): Uddannelse af den reflekterende praktiker - tiltag til en ny udformning af undervisning og laring for professionelle. Forlaget Klim.

Selwyn, N. (2008). Developing the technological imagination: Theorizing the social shaping and consequences of new technologies. In: Theorising the benefits of new technology for youth: Controversies of learning and development. Report of the seminar held on Wednesday 12 March 2008, Department of Education, University of Oxford. Retrieved from: http://eprints.lse.ac.uk/33821/1/Theorising_the_benefits_of_new_technolog y_for_youth.pdf

Skov, A. (2015). Hvad er digital kompetence? Center for Digital Dannelse: http://digitaldannelse.org/vidensbase/hvad-er-digital-kompetence/

Skov, A. \& Brøndum, J. (2015). Hvad betyder digital dannelse? Center for Digital Dannelse: http://digitaldannelse.org/vidensbase/hvad-betyder-digital-dannelse/

Toft, H. \& Nørgård, R.T. (2016). Pla(y)ceskabelse: når børn og robotteknologi mødes. Læring og Medier, No. 14, s. 1-31.

Valk, L., Bekker, L. \& Eggen, B. (2013). Leaving room for improvisation: towards a design approach for open-ended play. Proceedings of the $12^{\text {th }}$ International Conference on Interaction Design and Children (IDC '13), 92- 101. ACM, New York.

Vejledning for faget dansk: http://www.emu.dk/modul/vejledning-faget dansk\#fsnit-3-3-innovation-ogentreprenoerskab, afsnit 3,3.

Vygotsky, L.S. (1978). Mind In Society. Harvard University Press.

Winfield, A. (2012). Robotics. Oxford: Oxford University Press.

Video: Mølgaard, Jens Andersen \& Paaskesen, R.B. (2016): "Future-Tech-

Town year 2060":

https://www.youtube.com/watch?v=Zg7Nf27LrDA\&list=PLYoUzW5GhC

NCnvBi4GUi5LY_c8sCarG1

Video: Nørgård, R.T. \& Paaskesen, R.B. (2014):

http://codingpirates.dk/fremtidsoe-i- vejle/

Walter-Hermann, J. \& Büching, C. (Eds.) (2103). FabLab: Of Machines, makers, and inventors. Bielefeld: transcript Verlag. 